\title{
Thomas DILLINGER
}

\section{Srečevanje s suburbanizacijo na območju Bratislave}

Mejno območje med Avstrijo in Republiko Slovaško

Bratislava
Dunaj
Obrobna
območja
Regionalni razvoj
Suburbanizacija
Bratislava
Peripheral areas
Regional
development
Suburbanisation
Vienna

Bratislava

Dunaj

Regionalni razvoj

Bratislava

Regional

Suburbanisation

Vienna

\begin{abstract}
Širitev Evropske unije pomeni pomembno spremembo dosedanjega funkcionalnega teritorialne zgradbe Evrope. Globalne politične posledice so pretežno znane, težave, ki so hkrati priložnosti regionalnega in lokalnega razvoja, pa dobivajo stvarne razsežnosti. Predmet prispevka je podeželsko območje severovzhodne Avstrije, na katero vplivajo funkcijsko-gravitacijski suburbanizacijski učinki glavnega mesta sosednje države, kjer nastaja rastoča bratislavska aglomeracija.
\end{abstract}

\section{Uvod}

Rojen sem na Dunaju. Ko sem bil še otrok, sta se mi zdela Monaško (400 km od Dunaja) in Benetke (720 km od Dunaja) bližja kot Bratislava (60 km od Dunaja).

\subsection{Zgodovinski prelet}

Prispevek sledi rezultatom raziskovalnega projekta, opravljenega v letih 2003-2004 v okviru JORDES+ (Skupna regionalna razvojna strategija) Dunaj-Bratislava-Györ, ki je bil sofinanciran prek INTERREG III A. Delovni modul, poimenovan COBRA (orig. angl. Citybinterland Co-operation Bratislava okrajšava za projekt sodelovanja $\mathrm{v}$ zaledju Bratislave), obravnava mejno območje med Slovaško in Avstrijo v okolici Bratislave s poudarkom na desetih podeželskih lokalnih skupnostih v Avstriji, in sicer Marchegg, Engelhartstetten, Lassee, Hainburg, Wolfsthal, Berg, Kittsee, Edelstal, Pama in Deutsch Jahrndorf.

Eden od ciljev projekta je bil oceniti možnosti in težnje interakcij med Bratislavo in avstrijskimi lokalnimi skupnostmi ter oblikovati programsko metodo $h$ konceptu regionalnega razvoja za območje aglomeracije.[1]
Expansion of the European Union also implies significant functional changes in Europe's territorial system. Global political consequences are more or less known, while problems, which are also opportunities for regional and local development, are gaining real dimensions. The subject of this article is a rural area in North-eastern Austria, which is affected by functional-gravitational influences of Bratislava, the neighbouring country's capital city, where an expanding urban agglomeration is emerging.

Ko govorimo o obmestnem razvoju na avstrijsko-slovaški meji, ne smemo pozabiti zgodovinskih okoliščin. Nova meja, zarisana po prvi svetovni vojni na osnovi mirovne pogodbe iz Saint-Germaina, je regijo razdelila med državi Avstrijo in Češkoslovaško. Popolna ločitev nekoč strukturno izrazito povezanih regij se je zgodovinsko zgodila po drugi svetovni vojni z železno zaveso. Med hladno vojno med njima tako rekoč ni bilo nobenih stikov. $\mathrm{Za} »$ zahod « je bil to »konec sveta«, podobno videnje so krepili tudi na vzhodu.

Po padcu železne zavese leta 1989 se je počasi, zelo počasi, v tej regiji začel nov razvoj. Gre za težaven proces, ki še traja. Mejna območja se namreč srečujejo s specifičnimi težavami, še zlasti tista ob nekdanji železni zavesi:

- prva težava so različni jeziki; to je težava (morda predvsem evropska) vseh mejnih območij;

- druga težava so razlike v gospodarstvu; še zlasti ob nekdanji železni zavesi jo bo treba reševati vsaj vso generacijo;

- tretja težava so strahovi in predsodki v ljudeh, ki so živeli ob povsem zaprti meji več kot štirideset let; njihovo osebno vedenje o ljudeh na nasprotni strani meje je zelo omejeno ali celo nično; 
- četrta težava je »meja v miselnosti « ljudi na obeh straneh meje, kar pomeni, da njihova razmišljanja in zanimanja v vsem tem času niso bila usmerjena na nasprotno stran meje, temveč $\mathrm{v}$ prostor lastne $\mathrm{dr}$ Žave. Življenje ob »mrtvi« meji je ustvarilo sliko »življenja na obrobju « - na periferiji. Po odprtju meje so »obmejni prebivalci « kar naenkrat postali »središčni « in se srečujejo $\mathrm{z}$ izredno težkim procesom miselne reorientacije, ki še traja.

Avstrija je članica Evropske unije od leta 1995, Republika Slovaška pa od leta 2004. Med njima je zdaj še schengenska meja, toda tudi ta bo kmalu izginila.

\subsection{Regionalni okvir}

V regiji prevladujeta Dunaj in Bratislava, ki sta glavni mesti Avstrije in Slovaške. Skupaj imata več kot dva milijona prebivalcev. V prostoru aglomeracije Dunaj-Bratislava, ki vključuje tudi prostor Gradiščanskega, Spodnje Avstrije, Dunaja in območja Bratislave ter Trnave, živi več kot 4,5 milijona prebivalcev. ${ }^{[2]}$

Možnosti razvoja regije so velike. Njena pomembnost je bila poudarjena že leta $1993 \mathrm{v}$ študiji Proizvodni prostori zahodne in vzhodne Evrope (Empirica, Bonn, 1993). Za bratislavsko so ugotovili, da ima med vsemi raziskanimi regijami Evrope »najboljšo prihodnost «. [3]

Poleg tega sta v evropskem okviru Dunaj in Bratislava označena kot območji metropolitanske rasti (MEGA, orig. Metropolitan Growth Areas). Takšna tipološka opredelitev sledi analizam projekta ESPON 111: Potenciali za policentrični razvoj v Evropi, v katerem so prepoznali najmočnejše urbane regije v Evropi. [4]

$\mathrm{Na}$ prostoru med Dunajem in Bratislavo še vedno prevladuje kmetijstvo. Zlasti prostor severno od Donave, tj. Marchfeld, je eno najpomembnejših kmetijskih območij v Avstriji.[5] Južno od Donave leži t. i. Arbesthaler Hügeland, hribovito območje vinogradov in gozdov. ${ }^{[6]}$ Ob Donavi se razprostira narodni park Donau-Auen. V dolžini $38 \mathrm{~km}$ pokriva ves prostor ob Donavi med Dunajem in avstrijsko-slovaško mejo. Narodni park varuje enkratno krajino enega zadnjih večjih mokrišč v srednji Evropi, ki so jo oblikovale občasne poplave. $\mathrm{V}$ njem je najti redke živalske in rastlinske vrste. Poleg narodnega parka so na območju tudi drugi prostori zavarovane narave in območja Nature 2000 ter varovane kulturne krajine.

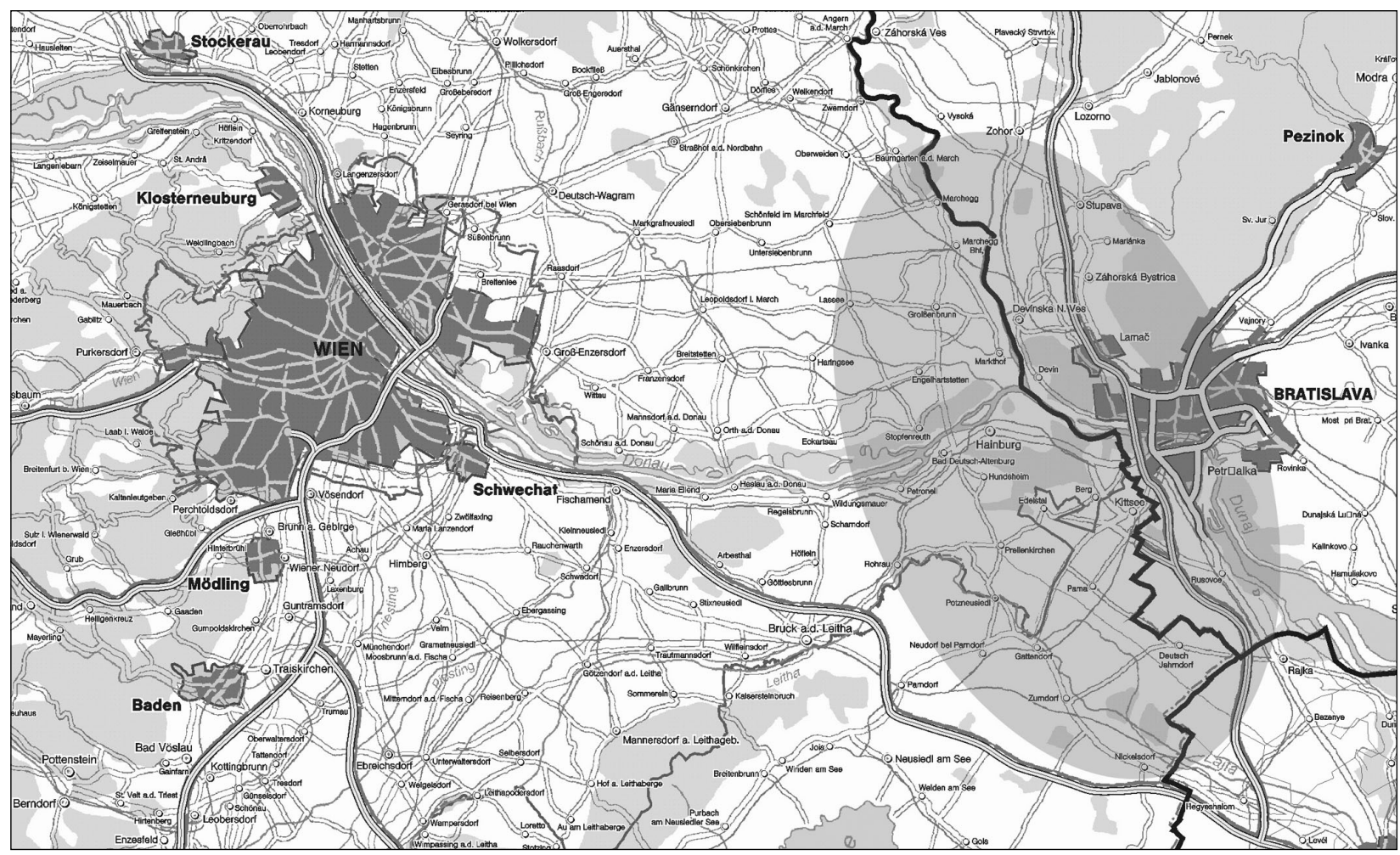

Slika 1: Območje obravnave (Vir: RC consulting, VITECC) 
Na tem območju je najpogosteje obravnavano vprašanje infrastrukturna povezava med Dunajem in Bratislavo. Posledica železne zavese je skrajno zanikrna povezava Dunaja $z$ vzhodom, z Bratislavo. Pogoj za razvoj vsega območja je prav izboljšana infrastruktura.

\section{Cestna infrastruktura}

Med mesti ni avtoceste. Jeseni 2004 so začeli graditi povezovalno avtocesto (A6, od mesta Bruck a.d. Leith, južno od Donave) od zdajšnje avtoceste med Dunajem in Budimpešto (A4) do Bratislave. Dokončali naj bi jo v letu 2007.

$\mathrm{V}$ razpravi je dodatna avtocesta na desnem bregu Donave. Za zdaj še iščejo najboljši koridor zanjo; rezultati bodo znani v letu 2005 .

\section{Železniška infrastruktura}

Med mestoma sta dve neposredni železniški povezavi. Hitrejša (Ostbahn) poteka južno od Donave. Najkrajši potovalni čas je 46 minut. Druga povezava je severno od Donave (Marchegger Ast). Potovalni čas je najmanj $64 \mathrm{mi}-$ nut. Ta povezava ni elektrificirana in je na posameznih delih enotirna. Izboljšanje razmer je nujno za učinkovitejše povezovanje.

Najstarejša železniška povezava je t. i. Pressburger Bahn (Pressburg je nemško ime za Bratislavo). Zgradili so jo v avstro-ogrski monarhiji. Toda danes tej progi manjka 8 $\mathrm{km}$ tirov, podrli so jih med Wolfsthalom in Bratislavo. Vsekakor bi ta linija zelo izboljšala povezave regije $\mathrm{z}$ mestoma.[7]

\section{Možnosti in težnje interakcij v obravnavanem prostoru $^{[8]}$}

V bližnji prihodnosti bodo lokalne skupnosti, ki so sicer v Avstriji, vendar ležijo v okolici Bratislave, po značaju postale obmestna naselja tega mesta. Njihov cilj je pripraviti se na nove razmere kar se da ustrezno, tako da bi se izognile najhujšim težavam suburbanizacije. Ta proces je treba dokončati najpozneje do trenutka vključitve Slovaške v schengensko območje, ko bodo razmere povsem in zares odprte. Do takrat morajo v lokalnih skupnostih oblikovati jasno sliko o tem, kakšno vlogo/funkcijo želijo imeti v bratislavski aglomeraciji.
Avstrijskih lokalnih skupnosti, ležečih severno od Donave, takšen razvoj ne bo prizadel tako močno kot tiste na jugu. Donava in območje močvirja sta še vedno zelo močni naravni oviri. Lahko pa pričakujemo linearni razvoj ob osrednjih prometnih infrastrukturah.

Na jugu se bodo srečali z zvezno rastjo Bratislave. Učinki razvoja bodo najizrazitejši zlasti v lokalnih skupnostih, ki ležijo najbližje mestu (Berg, Wolfsthal and Kittsee). Hitrosti tega procesa si nihče ne upa napovedovati, vendar lahko pričakujemo, da bodo lokalne skupnosti prej ali slej postale del enotne bratislavske prostorske enote.

\subsection{Problemi suburbanizacije}

Potenciali in težnje obmestja Bratislave se bodo $\mathrm{v}$ interakcijah srečali z značilnimi suburbanimi problemi, znanimi tudi iz drugih okolij. Zlasti obmestni, podeželski del, ki leži v Avstriji, bo imel takšne težave, saj je bil pred razvojem »zavarovan « z železno zaveso. Tu bom opisal osnovne težave podeželskih skupnosti, ležečih $\mathrm{v}$ bližini velikih mest, saj so najpogostejše in hkrati najpomembnejše.

\section{Urbana razrast in nenadzorovana raba zemljišč}

V vsej Evropi na mejah mestnih regij nastajajo območja razpršene namenske rabe, navadno povsem odvisne od rabe avtomobilov in brez kakovostnih urbanih prostorov. Takšen razvoj bo verjetno tudi v prihodnosti težko spremeniti: »Povpraševanje po nadaljnji rasti zazidljivih zemljišč za stanovanjsko gradnjo bodo tudi v prihodnje usmerjale potrebe po eno- in dvostanovanjskih stavbah. Pri trgovinskih območjih pa spoznavamo, da zaradi restrukturiranja nastaja stalna težnja po velikih prostorih, ki niso integrirani.« [9]

Zaradi pasovnega poselitvenega vzorca in pomanjkljive zgostitve takšnih območij je ob oseh, točkah ali vozliščih večja verjetnost uporabe motornih osebnih vozil. Težnjo krepi sprejemljivejša cena nepremičnin $\mathrm{v}$ obmestjih. Potovanja na obrobju so čedalje bolj »tangencialna« in/ali potekajo krožno. Upravljavci lokalnega javnega potniškega prometa se na takšne razmere komaj kje odzivajo. 


\section{Izguba dejavnosti - preoblikovanje podeželja}

Beg pred množico, ki ga povzroča suburbanizacija, pelje k stalni strukturni spremembi poseljenih prostorov podeželja. Urbane zgostitve se razširjajo $\mathrm{v}$ bolj ali manj razsežne aglomeracije, hkrati pa se mestno življenje, sicer v razvodeneli obliki, širi $\mathrm{v}$ okolico. Takšno »preoblikovanje « nekdanjih podeželskih območij se izraža v spremembah družbene strukture v najširšem pomenu izraza, toda tudi v fizični pojavnosti teh skupnosti. Podobno se krepijo urbani vplivi prav zaradi gravitacijskega učinka urbanih aglomeracij. Med drugim se ta učinek kaže v združbah komercialnih območij v neposredni okolici, močnem pretoku dnevnih migrantov in povečanem priseljevanju $\mathrm{Z}$ oddaljenih območij, ki je pretežno usmerjeno v središčna območja ter sosednje skupnosti.[10]

\section{Težave identitete}

Zaradi boljšega razumevanja težav s prepoznavnostjo je treba najprej opraviti kratek izlet $\mathrm{k}$ pomenom izraza identiteta. Prostor označen $z$ izrazom identitetni, je treba videti kot zaprt. Znotraj občinskih meja kaže svoj značaj, ki vsebuje jasno razumljive značilnosti in mu med različnimi prostori omogoča prepoznavnost. Identiteta je lastnost, ki določa člane skupnosti, jih tako uvršča ter zbira; prostor postane nepogrešljiv.[11]

Stanovanjska območja - velike stanovanjske soseske pa tudi območja enodružinskih hiš se čedalje bolj selijo na obrobja. V nasprotju z razvitimi bivalnimi območji, kjer opažamo delno ali popolnoma mešano rabo, večfunkcionalnost, »javno« in »lokalno« identiteto, imajo ta območja praviloma le osnovno infrastrukturo. »Decentralizirane koncentracije $\ll$ smislu razvoja območja tam ni. »Kje sem? Vse je videti podobno. Enake trgovine, enaki obroki $\mathrm{v}$ gostiščih, enaka umetnost $\mathrm{v}$ muzejih, enaki filmi v kinih.«[12] Takšna regularnost povzroča prebivalcem čedalje hujše težave pri prepoznavanju lastnega bivalnega prostora.

\section{Izguba krajine in prepoznavnosti}

$\mathrm{S}$ pasovnim razvojem, v nasprotju od osrediščenega, omejenega razvoja $v$ mestih ali obmestjih, na splošno izgubljamo kakovosti kulturne krajine, hkrati pa njeno prepoznavnost. Takšne izgube ni mogoče nadomestiti $\mathrm{z}$ gradnjo »območij « za posebne namene (npr. trgovinska, stanovanjska, industrijska območja ipd.). Izbrani vzorec pozidave obrobja hkrati pomeni razkroj prepoznavnosti mestnih robov. [13]

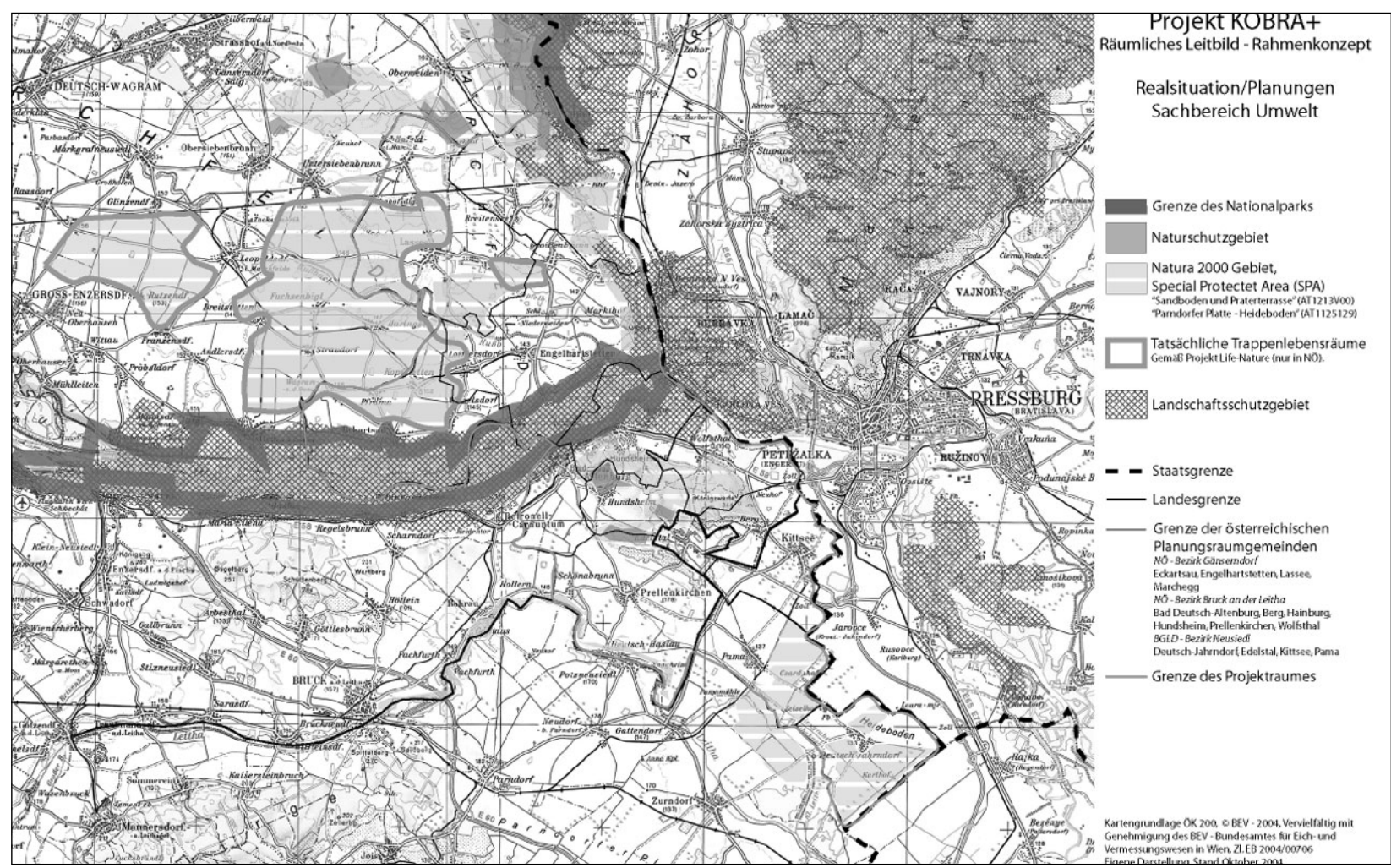

Slika 2: Zavarovana območja v regiji (Vir: Inštitut za urbanistično oblikovanje in prostorsko planiranje, Tehniška univerza Dunaj) 


\section{Programska metoda zasnove regionalnega razvoja prostora aglomeracije ${ }^{[14]}$}

\section{Proces spreminjanja je priložnost}

Pogled avstrijskih skupnosti v okolici Bratislave je še vedno usmerjen k Dunaju. Širitev Evropske unije, ki je velika priložnost prav za te skupnosti, kot takšna še vedno ni prepoznana $\mathrm{v}$ očeh lokalnih/regionalnih politikov. Morale bi se »zasukati « in neposredno pogledati k Bratislavi. Takrat bodo prepoznale svojo priložnost (vendar tudi tveganja) v spremenjenih okoliščinah.

Avstrijske skupnosti bi morale videti priložnost $v$ tem procesu preobrazbe, saj načelno omogoča nove razvojne perspektive.

Kulturne in ekološke kakovosti morajo biti v ospredju

Kulturne in ekološke kakovosti so najpomembnejše razvojne potrebe, saj bodo okrepile gospodarske prednosti. $\mathrm{V}$ prihodnosti bodo prav te kakovosti najpomembnejši gospodarski dejavniki, torej v času, ko bodo osnovne infrastrukture, npr. prometna ali ko- munikacija velikih hitrosti, dosegljive bolj ali manj povsod. Nujni cilj tega procesa preobrazbe mora potekati skupaj s spoštovanjem enkratnih lokalnih značilnosti in kakovosti, npr. kulturne dediščine in krajine.

\section{Razvijanje identitete}

$\mathrm{Za} \gg$ decentralizirano zgostitev « morajo skupnosti razviti identitete, osnovane na lastnem značaju, ki so preprosto vidne zunanjemu opazovalcu. Zdajšnje identitete avstrijskih skupnosti, ležečih v zaledju Bratislave, bodo $\mathrm{v}$ prihodnosti spremenjene pod njenim vplivom. Zato morajo že zdaj na novo opredeliti svojo vlogo in namen ter seveda razviti strategije izvajanja.

\section{Ohranjanje zemljišč za prihodnost}

Avstrijske skupnosti v zaledju Bratislave bodo v bližnji prihodnosti pod velikim pritiskom zagotavljanja zazidljivih zemljišč. V preteklosti so se območja naselij zmanjševala, v prihodnosti pa se bo proces dinamično obrnil. Da bi se izognili ireverzibilnim negativnim težnjam, je treba razviti strategije za ohranjanje zemljišč za razvoj. Cilj mora biti ohranjanje ekološko vrednih območij, najboljših kmetijskih zemljišč in zagotavljanje zadostnega prostora za prostočasne dejavnosti.

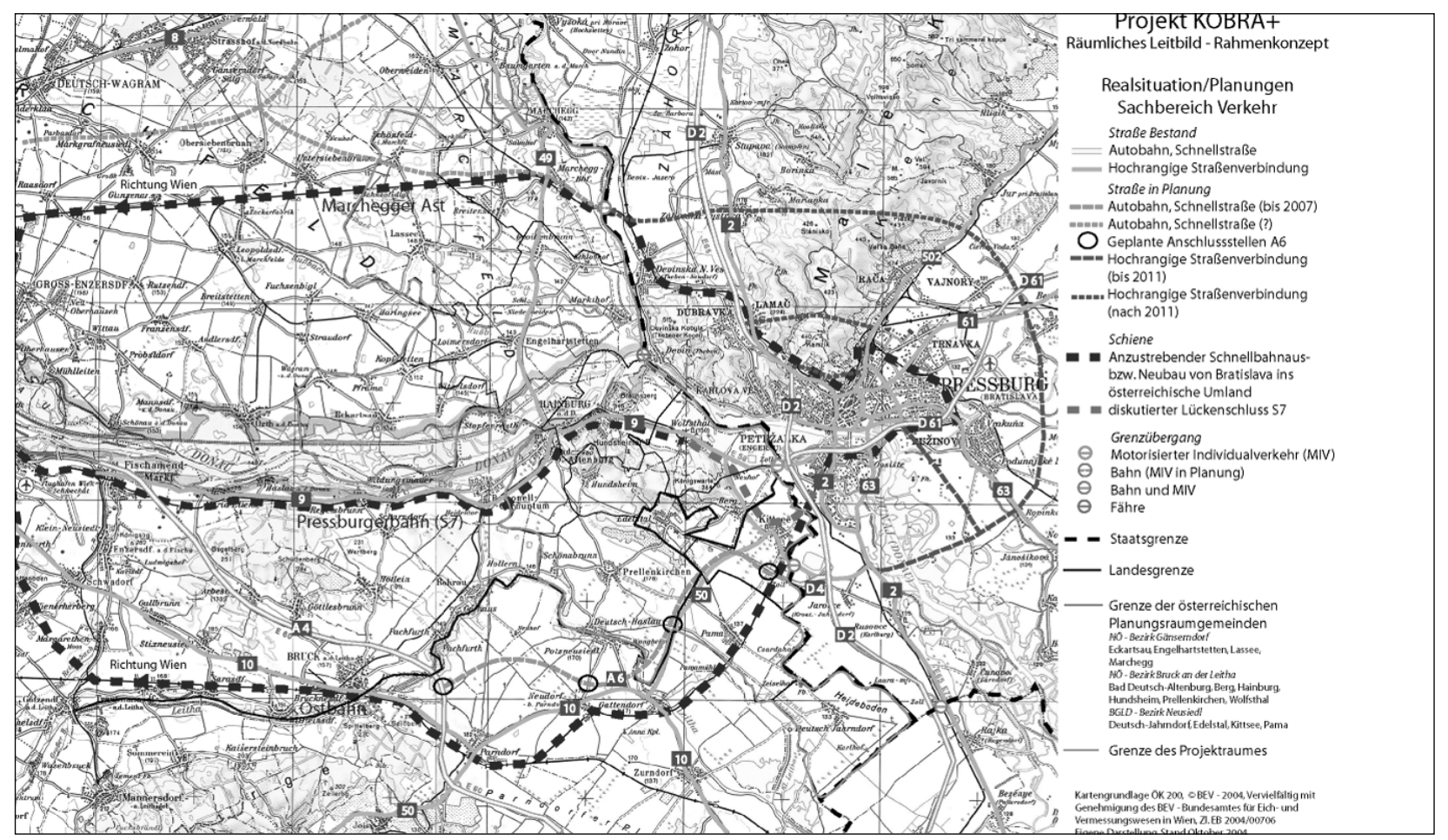

Slika 3: Prometne razmere/načrti v regiji (Vir: Inštitut za urbanistično oblikovanje in prostorsko planiranje, Tehniška univerza Dunaj) 
Načrtovanje gospodarskih dejavnosti v novih razmerah

Bratislava bo v prihodnosti vplivala tudi na gospodarsko strukturo avstrijskih skupnosti v svojem zaledju. Postala bo njihovo »gospodarsko središče «, kjer se bodo morali sprijazniti $\mathrm{z}$ novimi razmerami, hkrati pa razviti strategije za igranje izbrane (želene) vloge v tem gospodarskem prostoru. Pri tem je treba upoštevati tudi želje prebivalcev Bratislave.

Zgodba je pomembna tudi za kmetijski sektor. Trg kmetijskih pridelkov bo Bratislava. Eden od ciljev je okrepiti in povezati raziskovalne ustanove, delujoče v kmetijstvu, s sorodnimi raziskovalnimi in izobraževalnimi ustanovami v Bratislavi.

Zaradi povpraševanja po prostočasnih dejavnostih in rekreaciji v Bratislavi je treba tudi na tem področju razviti ustrezno ponudbo za različne ciljne skupine.

Iskanje trajnostnih in integriranih prometnih rešitev

Zaradi »železne zavese« danes med Bratislavo in zalednimi avstrijskimi skupnostmi ni integrirane prometne infrastrukture. Razmere so zato povsem neustrezne in ni mogoče sprejeti nove interakcije med mestom in zaledjem.
V primerjavi z drugimi aglomeracijami pa ima ta vsekakor prednost. Lahko se uči iz tujih napak in poišče vzdržno ter integrirano prometno rešitev zase.

Cilj javnega potniškega prometa mora biti povezava delujočega sistema $\mathrm{v}$ Bratislavi in zalednih skupnosti v Avstriji v enoten sistem.

\section{Ponovno ovrednotenje povpraševanja po zemljiščih}

Razpoložljivi izračuni potreb po zazidljivih zemljiščih ne odsevajo novih razmer. Ker je Slovaška postala članica Evropske unije, postaja za prebivalce Bratislave bivanje v eni od majhnih zalednih skupnosti (in dnevno potovanje v mesto v službo) čedalje zanimivejše. Tako se bodo morale spoprijeti s spremembami na trgu nepremičnin oziroma izrazito povečanim pritiskom. Svoje urbanistične zasnove bodo morale prilagoditi povpraševanju.

\section{Ohranjanje pogledov}

Zdajšnji pogledi na zaledna naselja so pomembni del identitete skupnosti. Ta se vsekakor nenehno spreminja. Gre za znan proces, ki traja desetletja, če ne stoletja. Hkrati se spreminja identiteta. Če proces poteka prehitro, se identiteta ne more razviti. Rezultat

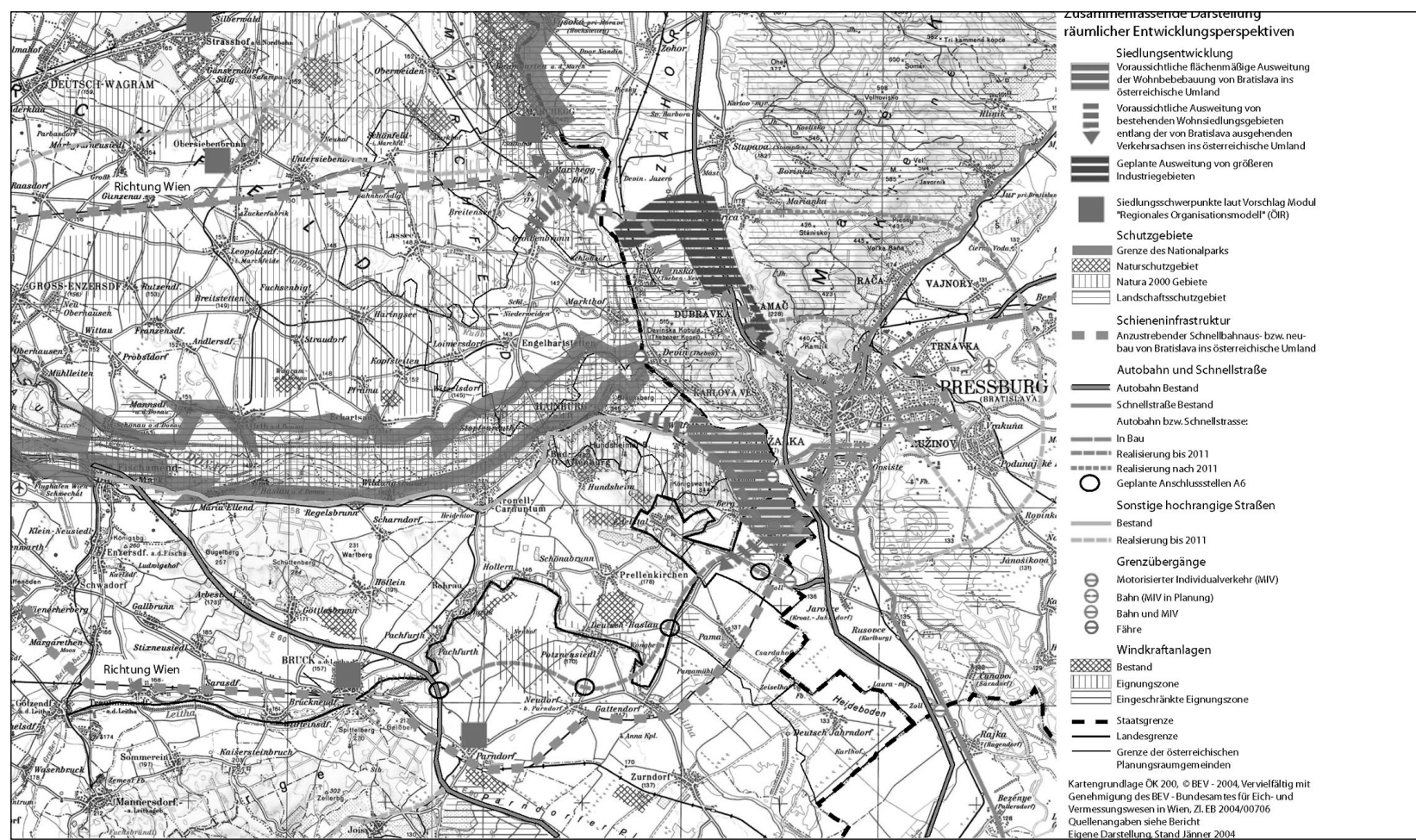

Slika 4: Razvojne perspektive (Vir: Inštitut za urbanistično oblikovanje in prostorsko planiranje, Tehniška univerza Dunaj) 
so prostori brez pomenov, imen, značaja, ki jih ni mogoče prinesti od drugod. Pričakujemo lahko dinamičen in hiter razvoj, zato bo varovanje pogledov na naselja pomembna naloga.

\section{Razvijanje osnov sodelovanja}

Za konec predstavljam še specifičen problem suburbanizacijskih razmer. Rešitve za nastajajoče probleme bodo nastale le iz skupnega delovanja Bratislave in omenjenih zalednih skupnosti. Torej, treba bo razviti ustrezno osnovo za sodelovanje. Naloga je zelo težka. Zaradi specifičnih okoliščin bo treba premagati mejo med dvema državama, kar pomeni tudi razlike med dvema sistemoma planiranja in planerskima kulturama, vemo pa, da je uravnavanje kompleksnih razmerij med mesti in obmestji težavno že, če so mesto in okoliške skupnosti v eni državi.

\section{Sklep}

Rezultat raziskovalnega projekta COBRA je, da so se avstrijske lokalne skupnosti odločile za skupni razvoj, kar je prvi korak k zasnovi regionalnega razvoja vsega območja. Zasnova bo dokončana sredi leta 2005 , nato jo bodo $\mathrm{v}$ drugem koraku predstavili pristojnim prostorskim planerjem $\mathrm{v}$ Bratislavi in jo uskladili.

Univ. ass. dipl.-ing. dr. techn. Thomas Dillinger, Tehniška univerza Dunaj, Inštitut za urbanistično oblikovanje in prostorsko planiranje, Avstrija E-pošta: tdilling@pop.tuwien.ac.at

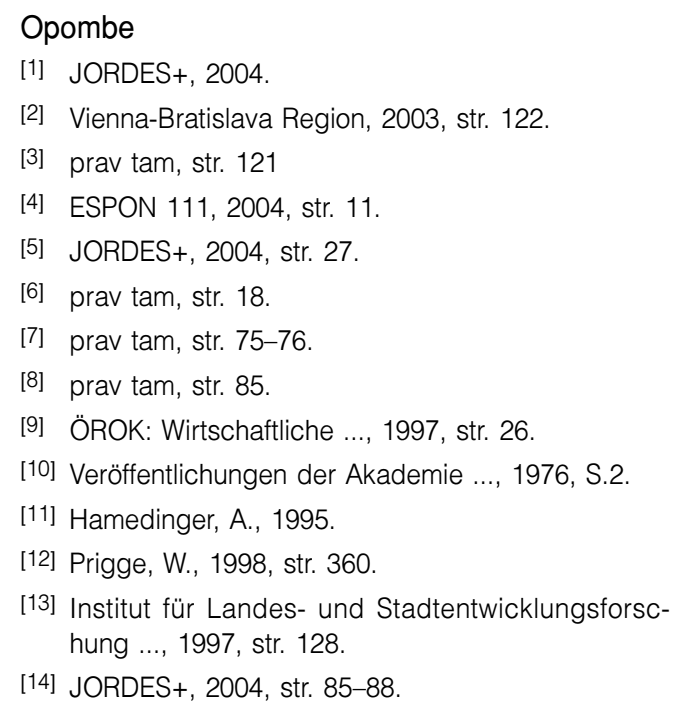

\section{Viri in literatura}

ESPON 111 (2004) Potentials for polycentric development in Europe, Project report.

Hamedinger, A. (1995) Freizeitpolitik und Stadtplanung zwischen "Festival« und »Grätzelkultur «, Dunaj.

Institut für Landes- und Stadtentwicklungsforschung des Landes Nordrhein-Westfalen, 1997

JORDES+ (2004) Gemeinsame Entwicklungsstrategien für die Region Wien-Bratislava-Györ, Endbericht Zusatzmodul: KOBRA Stadt-Umland Kooperation Bratislava; Institut für Städtebau und Raumplanung, Technische Universität Wien, mecca environmental consulting, Dunaj.

ÖROK (1997) Wirtschaftliche Entwicklungsperspektiven für die österreichischen Ballungsräume, Dunaj.

Prigge, W. (1998) Peripherie ist überall, Frankfurt/Main, New York.

Production areas of Western and Eastern Europe (1993) Empirica, Bonn.

Veröffentlichungen der Akademie für Raumforschung und Landesplanung, Zur Abgrenzung und inneren Gliederung Städtischer Siedlungsagglomerationen (1976) Band 112, S.2.

Vienna-Bratislava Region, Austrian Background report for the OECD, Territorial Review and Assessment and Recommendations of the OECD (2003) Vienna City Administration MA 18 - Department for Urban Development and Planning, Dunaj. 